\title{
Envenoming caused by a Portuguese man-o'-war (Physalia physalis) manifesting as purpuric papules
}

\author{
Envenenamento por caravela (Physalia physalis) manifestando-se com erupção \\ papulopurpurica
}

Yamin José Risk ${ }^{1}$
Vidal Haddad Junior

\author{
João Luiz Costa Cardoso ${ }^{2}$
}

The Phylum Cnidaria (jellyfish, Portuguese man-o'-war, anemones and corals) comprises animals with stinging cells with toxin-producing organelles, the nematocysts. ${ }^{1}$ Portuguese man-o'-war are cnidarians of the Hydrozoa class. They are not true jellyfish, but colonies of polyps, with a floater (similar to a purple balloon) and long tentacles to capture fish (Figure 1). The tentacles and other parts of their body present venomous cells, the cnidocytes. The venom initially causes immediate intense pain (neurologic effect) and linear erythema and edema marking the points of con- cor

tact (dermatonecrotic effect). Late manifestations include chronic inflammation and local pigmentation. ${ }_{1,2,3}$ The image shows linear lesions in a 42 year-old woman, who, while bathing on a beach in the State of Alagoas (Brazil), felt something "curl up in her leg, like a rope" and saw a Portuguese man-o'-war nearby (Figure 2). The pain was immediate and there were local erythema and edema, characterized by a typical cnidarian injury. On the following day, the marks had become darker. On dermatological examination, the

Approved by the Advisory Board and accepted for publication on 13.10.2011.

* Work conducted at Vital Brazil Hospital - Butantan Institute - São Paulo (SP), Brazil.

Conflict of interest: None

Financial funding: None

Infectologist, Vital Brazil Hospital - Butantan Institute - São Paulo (SP), Brazil.

Dermatologist, Vital Brazil Hospital, Butantan Institute - São Paulo (SP), Brazil.

Dermatologist; Professor (PhD), Botucatu School of Medicine, Universidade Estadual Paulista "Júlio de Mesquita Filho" - São Paulo State University - (FMBUNESP) - Collaborating Physician, Vital Brazil Hospital - Butantan Institute - São Paulo (SP), Brazil. 


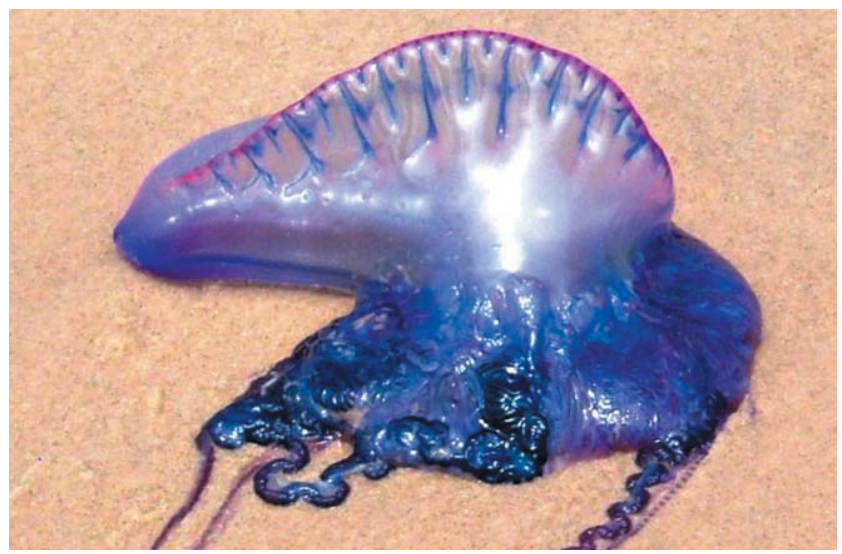

Figure 1: Physalia physalis, the Portuguese man-o'-war, one of the cnidarians that causes envenoming in the Brazilian Coast. Note the floater and retracted tentacles

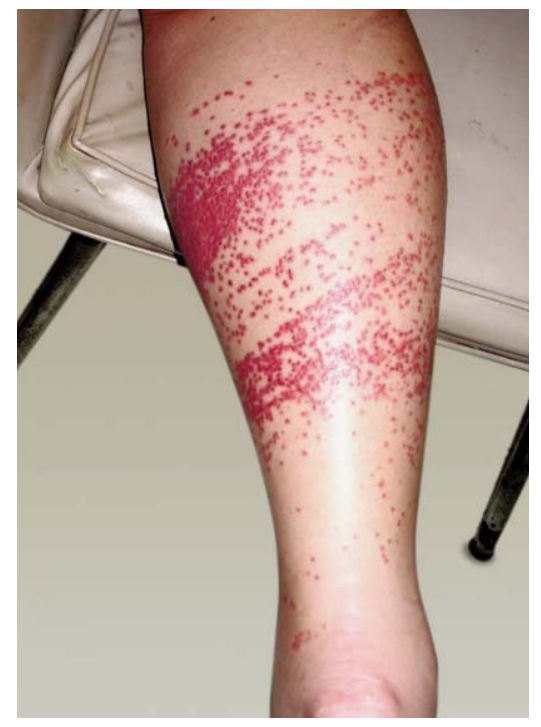

Figure 2: Linear purpuric papules reproducing tentacles in the left calf of the patient, one week after the envenoming patient presented with linear purpuric papules reproducing the shape of tentacles on her left leg, up to the calf. Blood tests were normal and the lesions faded after about a week, completely disappearing one month after the appointment. Purpuric manifestations are anomalous in this kind of envenoming and the exact reasons for them are not clear. It may be possible that the venom compromised the superficial vessels of the skin, but other envenoming episodes causing more severe inflammatory processes did not lead to the purpuric lesions observed in the patient. ${ }^{1-5} \square$

\section{REFERENCES}

1. Haddad Jr V. Animais aquáticos potencialmente perigosos do Brasil: guia médico e biológico. São Paulo: Editora Roca; 2008.

2. Haddad Jr V, Silveira FL, Cardoso JLC, Morandini AC. A report of 49 cases of cnidarian envenoming from southeastern Brazilian coastal waters. Toxicon. 2002; 40:1445-50.

3. Haddad Jr V, Franca FOS, Wen FH, Cardoso JLC. Acidentes provocados por celenterados: aspectos clínicos e terapêuticos. An Bras Dermatol. 1997;72:206-10.

4. Haddad Jr V, Silva G, Rodrigues TC, Souza V. Injuries with high percentage of systemic findings caused by the cubomedusa Chiropsalmus quadrumanus (Cnidaria) in Southeast region of Brazil: report of ten cases. Rev Soc Bras Med Trop. 2003; 36:84-5.

5. Haddad Junior V, Silveira FL, Migotto AE. Skin lesions in envenoming by cnidarians (Portuguese man-of-war and jellyfish): etiology and severity of accidents on the Brazilian coast. Rev Inst Med Trop Sao Paulo. 2010;52:47-50.

\author{
MAILING ADDRESS / ENDEREÇO PARA CORRESPONDÊNCIA: \\ Vidal Haddad Junior \\ Caixa Postal 557 \\ 18618000 - Botucatu, SP \\ Pbone./fax: 1438824922 \\ E-mail: haddadjr@fmb.unesp.br
}

How to cite this article: Risk YJ, Cardoso JLC, Haddad Jr V. Envenoming caused by a Portuguese man-o'-war (Physalia physalis) manifesting as purpuric papules. An Bras Dermatol. 2012;87(4):644-5. 